\title{
Development of an Optimization Model of Water Abstraction on River Osun
}

\author{
${ }^{1}$ Adegbola A.A., ${ }^{2}$ Adeyokunnu A.T and ${ }^{3}$ Olaniyan O.S. \\ ${ }^{1,3}$ Department of Civil Engineering, Ladoke Akintola University of Technology, Ogbomoso, Nigeria. \\ ${ }^{2}$ Osun State College of Technology, Esa Oke, Osun State \\ Corresponding Author: osolaniyan@lautech.edu.ng, +2348065155439
}

\begin{abstract}
Water is vital for any life process and there can be no substitute for it, and water serves many other useful purposes. Water supply to residents in Osun State is inadequate due to non-existence of schedule planning for water abstraction by related body.

This study investigated the development of an optimization model for water abstraction on River Osun. The model developed was a linear regression approach considering the effects of previous and current water abstraction. Fifty (50) years rainfall data collected from 1963-2012 were used to estimate corresponding runoff using rational approach method. The rainfall intensities were regressed against runoff and the corresponding generated runoff arrived at correlation co-efficient of 0.762 and 0.770 , respectively.
\end{abstract}

The water abstraction based on optimization model could serve as a hydrological input in the development of water abstraction by related body on River Osun. The developed optimization model is useful for effective river abstraction quantification.

Keywords: Water, Modeling, Optimization, Abstraction

\section{Introduction}

Water is vital for any life process and there can be no substitute for it. Abdulkarim and Baala (2008), described water as the vital requirement for human survival and it serves many other useful purposes for domestic, agriculture and industrial consumption. The main important source of water in any area is rain and it has drastic effect on water abstraction.

Osun River takes its source between Igede and Ijero in Irepodun/Ifelodun Local Government Area (LGA) of Ekiti State, and flow through south westward through Oke Imesi Ekiti before moving into Osun State and flows through Esa-odo, Idominasi, Osunjela, Local government Area (LGA) which supplies the city of Ibadan with approximately seventy (70) percent of its water (Abdulkarim and Baala ,2008).

The main socio-economic activities of people living around the Osun River are farming and fishing with little population into sand dredging. Basher et al. (2006) observed that people use the water from the river for domestic purpose, fishing, recreation, and washing. Sand dredging activities also take place along the river water course in these areas.

There are many dams on Osun River such as Asejire dam, Erinle dam, Ede dam, Esa-Odo dam, Apara, Aponje, and Owalla dam. The five functioning dam out of those dams are Ede, Erinle, Aponje, Apaara, and Esa-Odo dam in Osun State, Nigeria, from which they supply potable water abstracted to Osun State, while Esa-Odo supplied water to international breweries. Otin River was impounded in Eko-Ende Area, which is about $370 \mathrm{sq} . \mathrm{km}$ in Odo Otin Local Government Area in the north-east (Adeboye and Alatise, 2007).

The hydrologist finds it difficult to make accurate prediction of water abstraction by various dams using limited historic information of rainfall and runoff. These could be attributed to lack of trained personnel and equipment used for adequate assessment of these quantities on systematic basis where these data are available, they are characterized by gaps, which in most cases limit the inferences from their statistical analysis and eventually lower their usefulness for water quantification (Olaniyan, 2014). Using mathematical equations and statistical models, these gaps can be filled using stochastic hydrology.

The common and result oriented probability distributions in use are normal, log-normal and the Log Pearson Type (III) which fit adequately to the analysis. The use of frequency analysis have long been advocated for, the subject of plotting positions is not new to hydrologists. Plotting position have been used in estimating magnitude of hydrological events and their return periods, fitting distribution to data and elevating of frequency models. A variety of plotting position formula has been proposed in hydrological and statistical literature during the past 50 years(Olaniyan, 2014). 
Rainfall-Runoff analysis involves estimation and computation of stream flow at various locations in a watershed resulting from a given precipitation input. The hydrologic cycle is the basic concept on to which flood is derived, it comprises all the physical processes that affect the movement of water in its various forms (Regunath, 2006, Adamec, 2008)). A rational approach translates rainfall into runoff by assuming a runoff coefficient based upon catchment characteristics (Hughes, 2009).

\section{Methodology}

This research was designed for River Osun located within Osun State. River Osun has five major dams; one of these dams abstract water for industrial uses, while the other four dams abstract water for domestic uses. River Osun is located in an area whose boundaries are approximately longitudes

$$
Q=\mathrm{CI} \Lambda
$$

Where: $Q=$ Runoff in $\left(\mathrm{m}^{3}\right), \mathrm{I}=$ Rainfall Intensity in $(\mathrm{mm}), \mathrm{A}=$ Catchment area in $\left(\mathrm{m}^{2}\right)$ $\mathrm{C}=$ Runoff Coefficient

Table 1:Simplified Table of Rational Method for Runoff Coefficients

\begin{tabular}{ll}
\hline Ground cover & $\mathbf{0 . 0 5}-\mathbf{0 . 3 5}$ \\
\hline Lawns & $0.05-0.25$ \\
Forest & $0.1-0.5$ \\
Meadow & $0.1-0.25$ \\
Parts, cement areas & $0.1-0.3$ \\
Unimproved areas & $0.12-0.62$ \\
Pasture & $0.12-0.62$ \\
Industrial areas. & $0.5-0.9$ \\
Asphalt streets & $0.7-0.95$ \\
Concrete street & $0.7-0.95$ \\
Urban area & $0.3-0.5$ \\
\hline
\end{tabular}

(Source: Ragunath, 2006)

The rainfall and runoff relationship was established using regression analysis in order to determine the generated runoff. The annual rainfall were ranked in descending order of magnitude. The probabilities that ranked annual maximum rainfall will be equaled or exceeded in any year were determined by the Hazen's and Weibull plotting position. The Hazen plotting position was used in the study and is represented by equation 2

$$
Q_{T}=\frac{M-0.5}{n}
$$

Where; $\mathrm{Q}_{\mathrm{T}}=$ estimated return period to be equaled or exceeded, $M=$ rank of rainfall data

$\mathrm{n}=$ number of years of study.

The return period of anticipated rainfall were determined by finding the reciprocal of the exceedence probability and is expressed in equation 3

$$
\mathrm{T}_{\mathrm{r}}=\frac{1}{p}
$$

Where: $\mathrm{T}_{\mathrm{r}}=$ Return Period, $\mathrm{P}=$ Probability of exceedence

The weibull plotting position was also used and is represented by equation 4

$$
\mathrm{Q}_{\mathrm{T}}=\frac{m}{n+1}
$$

Frequency Analysis of Rainfall Data was done using Normal, Log-Normal and Log Pearson Type III distribution as described by their probability density function in equations $5-7$

$$
F_{(z)}=\frac{1}{\sqrt{2 \pi}}\left(e \frac{-z 2}{z}\right)
$$

Where: $Z$ = standard normal variable, and $E=$ equivalent 


$$
\begin{gathered}
\mathrm{F}_{(\mathrm{x})}=\frac{1}{x \sqrt{2 \lambda}} \exp \left(\frac{-y-N_{y}}{2 \sqrt{y^{2}}}\right) \\
\bar{y}=\frac{1}{\Lambda} \sum_{i=1}^{n} \log Q_{\max } \\
S_{y}=\sqrt{\frac{\sum_{i=0}^{n}(y-\bar{y})^{2}}{n-1}}
\end{gathered}
$$

Where; $\mathrm{Y}=$ Mean of $\mathrm{y}(\mathrm{mm}), \mathrm{S}_{\mathrm{v}}=$ Standard Deviation $(\mathrm{mm}), \mathrm{Y}=\log \mathrm{Qmax}(\mathrm{mm})$, and $\mathrm{n}=$ number of years

$$
\begin{array}{cl} 
& f_{x}=\frac{\lambda^{B}(y-e)^{B-1} e^{\lambda 9 y-e}}{x r} \\
\text { Where: } y=\log _{x}, \quad \lambda=\frac{5_{y}}{\sqrt{B}}, \quad B=\left(\frac{2}{C_{s}(y)}\right)^{2} & \square=\bar{y}=s_{y \sqrt{B}}
\end{array}
$$

The population growth rate of Osun state was determined using arithmetic progression method in equation 8

$$
\mathrm{P}_{\mathrm{n}}=\mathrm{P}_{0}\left(1+\frac{r}{100}\right)^{\mathrm{n}} \quad \text { । }
$$

Where: $P_{n}=$ future population after $n$ decades, $P_{0}=$ Initial population i.e the population at the end of last known census, $\mathrm{n}=$ Numbers of decades, $\mathrm{r}=$ Assumed growth rate $(\%)$

$$
\mathbf{r}=\sqrt[t]{\frac{P_{2}}{P_{1}}}-1
$$

where: $P_{1}=$ Initial known population, $P_{2}=$ Final known population , $t=$ Numbers of decades period between $P_{1}$ and $\mathrm{P}_{2}$

The future projection of water abstraction by Esa-odo, Aponje, Erinle, Apara and Ede dam was done by taking into consideration the population increase and the rate of consumption of water per various types of water demand. . The total consumption in this demand generally amounts to $55 \%$ of the total water consumption. The quantities of water required for industrial purposes as per IS: 1172-1963) Indian standard code of basic requirements for water supply is $25 \%$ of the total demand for industrial purposes.

The governing equation for the optimization model were derived by using linear programming method of general form in equation 10

$$
\operatorname{Max}(\operatorname{Min}) z=F\left(x_{1}, x_{2} \ldots x_{12}\right)
$$

An objective function was developed to measure system performance under a given regulating policy. The objective function of optimization for water abstraction was to maximize and minimize the linear programming model

$$
\begin{gathered}
g_{1}\left(X_{1}, X_{2} \ldots X_{n}\right) \leq=\text { or } \geq b_{1} \\
g_{1}\left(X_{1}, X_{2} \ldots X_{n}\right) \leq=\text { or } \geq b_{2} \\
g_{m}\left(X_{1}, X_{2} \ldots X_{n}\right) \leq=\text { or } \geq b_{m}
\end{gathered}
$$

Where: $\mathrm{Z}$ is the objective function, $\mathrm{F}=$ coefficient, and $\mathrm{x}=$ monthly data.

$\left(X_{1}, X_{2} \ldots . . X_{n}\right)$ is the decision variables.

$\mathrm{Z}=\mathrm{F}\left(\mathrm{X}_{1}, \mathrm{X}_{2} \ldots \ldots \mathrm{Xn}\right)$ is the objective function that is to be maximize or minimized.

The water abstraction operating policy should conform to the system layout. The abstraction rule were important constraints used to define the upper bound and lower bound during optimization. The constraints are in the form of errotione $f=$ ) nrinemalitioc $(<$ and $>1$

$$
\left\{\begin{array}{c}
g_{1}\left(X_{1}, X_{2} \ldots X_{n}\right) \\
g_{2}\left(X_{1}, X_{2} \ldots X_{n}\right) \\
g_{m}\left(X_{1}, X_{2} \ldots X_{n}\right)
\end{array}\right\}=\text { Constraint }
$$

Any combination of values $X_{y}, X_{2}, \ldots, X n$ that satisfies constraints in equation 10 is a feasible solution to the optimization model.

The optimization problem was formed to equation 13 


$$
\operatorname{Min} Z=C_{1} x_{1}+C_{2} x_{2}+C_{3} x_{3} \ldots+C_{12} x_{12}
$$

Where: $\mathrm{Z}=$ objective function, $\mathrm{C}_{1}=$ Quantity of water abstracted, by the facilities , $\mathrm{X}_{1}=$ Decision Variable

Equations (12 and 13) indicate that quantity of water abstracted is a function of generated runoff. The linear optimization problem was implemented in Excel spread sheet and solver formulation produces the solution of the optimization of abstraction of water by domestic and ind ustrial facilities abstracting water River Osun.

The quantity of water abstracted by domestic industrial purposes were determined at 55 and $25 \%$ of water generated before optimization problem were formed using equation (18).

Water Demand was projected till 2056 on River Osun using arithmetic population growth rate in equation 14

$$
\mathrm{P}_{\mathrm{n}}=\mathrm{P}_{0}\left(1-\frac{r}{100}\right)^{\mathrm{n}}
$$

Where: $P_{n}=$ future population after $n$ decades, $P_{0}=$ Initial population i.e the population at the end of last known census, $\mathrm{n}=$ Numbers of decades, $\mathrm{r}=$ Assumed growth rate $(\%)$

$$
\mathbf{r}=\sqrt[l]{\frac{P_{2}}{P_{1}}}-1
$$

Where: $P_{1}=$ Initial known population , $P_{2}=$ Final known population $t=$ Numbers of decades period between $P_{1}$ and $\mathrm{P}_{2}$ population growth rate $(\mathrm{r})$

$$
\mathbf{r}=\sqrt[2]{\frac{P_{2}}{H_{1}}}-1
$$

The National Population Commission (NPC) has provided the 1991 census figures and 2006 census figures. This figure was used as a basis for the projection of population.

\section{Results and Discussion}

The determined probabilities of exceedence of the peak rainfall before subjecting them to the statistical distribution are shown in Table 2. It was thus observed that the Hazen return period decreases as the rainfall year ranked in descending order so also the probabilities of exceedence increases. Similar trend was observed in Weibull plotting position. The probabilities exceedence for Hazen's and Weibull distribution plotting position tends to unit value. This is also in line with previous findings of Adeboye \& Alatise (2007).

Table 2: Frequency Analysis of Rainfall data on river Osun(1993-2012)

\begin{tabular}{ccccccc}
\hline Rank & Year & $\begin{array}{c}\text { Ranked maximum } \\
\text { rainfall }(\mathrm{mm})\end{array}$ & $\begin{array}{c}\text { Hazen return } \\
\text { veriod }\end{array}$ & $\begin{array}{c}\text { Exceedence } \\
\text { probabilitv }\end{array}$ & $\begin{array}{c}\text { Weibull return } \\
\text { veriod }\end{array}$ & $\begin{array}{c}\text { Exceedence } \\
\text { probabilitv }\end{array}$ \\
\hline 1 & 2012 & 1173.80 & 100 & 0.01 & 51.00 & 0.02 \\
2 & 2011 & 1241.30 & 33.33 & 0.03 & 25.50 & 0.04 \\
3 & 2010 & 1271.60 & 20 & 0.05 & 17.00 & 0.06 \\
4 & 2009 & 1310.20 & 14.29 & 0.07 & 12.75 & 0.08 \\
5 & 2008 & 1288.90 & 11.11 & 0.09 & 10.20 & 0.10 \\
6 & 2007 & 1421.70 & 9.09 & 0.11 & 8.50 & 0.12 \\
7 & 2006 & 1275.50 & 7.69 & 0.13 & 7.29 & 0.14 \\
8 & 2005 & 1129.21 & 6.67 & 0.15 & 6.38 & 0.16 \\
9 & 2004 & 1337.30 & 5.88 & 0.17 & 5.67 & 0.18 \\
10 & 2003 & 1422.20 & 5.26 & 0.19 & 5.10 & 0.20 \\
11 & 2002 & 1217.90 & 4.76 & 0.21 & 4.64 & 0.22 \\
12 & 2001 & 1014.90 & 4.35 & 0.23 & 3.92 & 0.24 \\
13 & 2000 & 1063.73 & 4.00 & 0.25 & 3.64 & 0.26 \\
14 & 1999 & 1112.60 & 3.70 & 0.27 & 3.40 & 0.28 \\
15 & 1998 & 1050.30 & 3.45 & 0.29 & 3.19 & 0.30 \\
16 & 1997 & 1229.90 & 3.23 & 0.31 & 3.00 & 0.31 \\
17 & 1996 & 1341.50 & 3.03 & 0.33 & 2.83 & 0.33 \\
18 & 1995 & 1452.52 & 2.86 & 0.35 & 2.68 & 0.35 \\
19 & 1994 & 1606.10 & 2.70 & 0.37 & 0.39 & 0.37 \\
20 & 1993 & 1263.80 & 2.56 & & & 0.39 \\
\hline
\end{tabular}


The developed rainfall-runoff relationship was of the form $y=11200 x-11170$ in September, 2011. This generated runoff varied from $56.26-15572.10 \times 10^{3} \mathrm{~m}^{3}$ as the year is increases The generated runoff on River Osun from 20032012 is presented in Figure 1. The monthly average runoff generated on River Osun was estimated in thousand per cubic meters at the from 1983 to 2012 shows peak runoff values between September and October.

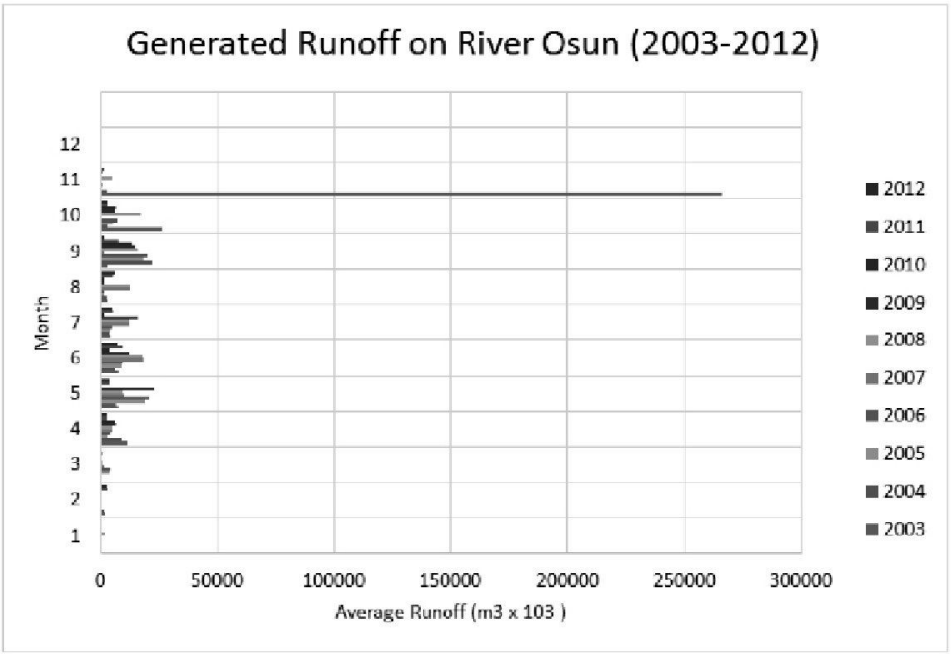

Figure 1: Generated Runoff on River Osun (2003-2012)

Erinle, Ede, Apaara and Aponje dam abstract water from River Osun for domestic purposes. Erinle Dam was located in Erinle which supply water to people living in Ilobu, Ifon and its environment. Ede Dam was located in Ede which supply water to people living in Ede Osogbo, Ido-Osun and Offatedo. Apaara dam was located in Kajola which supply water to people living in Kajola, Oora, Ilesha and its environment. Aponje dam was located in Iwo town, which supply water to people living in Iwo and its environment. Most of the supplied by these dams are categorized under domestic water demand. International practice mandates that water abstraction should not exceed $85 \%$ for rivers to allow some $15 \%$ to support aquatic life.

The total consumption in this demand, generally amounts to 55 to $60 \%$ of the total water as per IS:1172-1171. The quantity of water abstracted for domestic purpose (Ede, Erinle, Apara and Aponje dam) are $55 \%$ of monthly runoff generated on River Osun. The optimal abstraction of water by domestic does not exceed total water appropriation. While for industrial purposes, it follows similar trend. The water abstraction for domestic purposes and industrial purpose should not abstract more than $682 \times 10^{3} /$ day and $48201.32 \times 10^{3} /$ day so as not to jeopardize the mutual benefit of water abstraction.

The water demand by the domestic and industrial water needs from River Osun do not exceed $85 \%$ while the remaining $15 \%$ is for aquatic life according to international water control Art, 1972) state here that the abstraction, should not exceed $85 \%$. The remaining $15 \%$ was used to estimate the quantity of water required by aquatic life.

The optimal abstraction values for upper bound and lower bound for Ede Dam, Erinle Dam, Apara Dam, and Aponje Dam are $93071 \times 10^{3}$ and $0.10 \times 10^{3}$ cubic metres for monthly abstraction which was thus observed in December, 1996 and December, 2011. While the total minimum and maximum abstraction which is the objective function that was maximized and minimized as $\mathrm{z}=97306.63 \times 10^{3} \mathrm{~m}^{3} / \mathrm{yr}$. and $\mathrm{z}=827.97 \times 10 \mathrm{~m}^{3} /$ year, respectively. Water demand projection on River Osun in based on the population growth is presented in Table 3.

Table 3: Water Demand Projection for Facilities Abstracting Water from River Osun

\begin{tabular}{llll}
\hline Year & Population & \multicolumn{2}{l}{ Average Water Demand $\left(10^{6} \mathrm{~m}^{3} / \mathrm{yr}\right)$} \\
\cline { 3 - 4 } & & Industrial & Domestic \\
\hline 2016 & $3,740,923$ & 230.81 & 507.78 \\
2026 & $3,853,216$ & 240.83 & 529.82 \\
2036 & $3,968,815$ & 248.05 & 545.71 \\
2046 & $4,087,871$ & 255.50 & 562.09 \\
2056 & $4,210,263$ & 260.42 & 573.51 \\
\hline
\end{tabular}




\section{Conclusion}

The following conclusions can be drawn from the study:

(i) The runoff was at its peak between September to November.

(ii) The quantities of water abstracted for industrial purpose is higher than that of domestic purpose.

(iii) The derived optimization model using linear programming is capable of forecasting water demand projection and water abstraction system satisfactorily

The developed optimization modeled for water abstraction should be implemented for water abstraction system on River Osun.

\section{REFERENCES}

Adamec, M. J. (2008). Estimation of rainfall - runoff using GIS. In Journal of Hydrology and Hydromechanic 56 (4): 257-271.

Abdul-Karim, M.D and Bala, J.U (2008). A comparism of three plotting position used in flood frequency analysis in Eko-Ende. Hydrol.SG.J. 36(1), 141-152

Basher K. E., Mutua F., Muhungu D.M., Deksyos T. and Shanseidro A. (2006). Appraisal Study to select suitable Rainfall-Runoff model(s) for the Nile River Basin. 23(2)3242-3245.

Hughes, D. A. (2009). Monthly rainfall runoff models applied to arid and semiarid catchments for water resource estimation purposes. Hydrology Sci. 40 (6), 751-769.

Olaniyan, 2014. Numerical Modelling of Sediment Transport in River Omi South- Western Nigeria. PhDThesis, Department of Civil Engineering, Ladoke Akintola University of Technology, Ogbomoso, Oyo State, Nigeria.

Ragunath, M. H. (2006) Hydrology principle and Analysis of design. Revised second edition.

Sangati, M and Borga, M. (2009) Influence of Rainfall Spatial Resolution on Flash Flood Modelling. Nat Hazands Earth System, Sci, 9:575-584. 